\title{
Cylindrocladium spathiphylli, Causal Agent of Spathiphyllum Root and Collar Rot in the Federal District - Brazil
}

\author{
Ailton Reis ${ }^{1}$, Reginaldo G. Mafia ${ }^{2}$, Patrícia P. Silva ${ }^{1}$, Carlos A. Lopes $^{1}$ \& Acelino C. Alfenas ${ }^{2}$ \\ ${ }^{1}$ Embrapa Hortaliças, Cx. Postal 218, CEP 70359-970, Brasília-DF, e-mail: ailton@cnph.embrapa.br; ${ }^{2}$ UFV, Depto. de \\ Fitopatologia, CEP 36571-000, Viçosa-MG
}

(Accepted for publication on 06/11/2003)

Corresponding author: Ailton Reis

\section{RESUMO}

Cylindrocladium spatiphylli agente causal de podridão de colo e raiz do lírio da paz no Distrito Federal

Relata-se uma podridão de raiz e coleto em plantas de lírio da

Spathiphyllum wallisii Rengel is a popular ornamental plant of the family Araceae locally known as "espatifílio", "bandeira branca" or "lírio da paz". In 2003, potted plants of this species grown in a commercial greenhouse showed leaf yellowing and wilting (Figure 1-A) due to a collar and root rot (Figure 1-B) which later killed most of the diseased plants. Isolations from the border of infected tissues on PDA amended with rifampicin $(30 \mathrm{ppm})$ and ampicilin $(50 \mathrm{ppm})$ consistently yielded a fungus with a white micelium that turned brown after one week of incubation at room temperature. Microscopic observations of whitish fungal structures (Figure 1-F) at the center of the colony revealed conidiophores, conidia, and vesicles typical of the genus Cylindrocladium (Figure 1-C). The pathogenity test was performed in greenhouse $\left(20-35^{\circ} \mathrm{C}\right)$ using ten healthy plants derived from tissue culture and grown in sterile substrate in 1.51 pots. Plants were inoculated either by dipping clipped roots in a spore suspension $\left(10^{5}\right.$ conidia/ $\mathrm{ml}$ ) or by pouring $10 \mathrm{ml}$ of the same suspension on the base of the stem. Plants used as controls were treated with sterile water only. Disease symptoms first appeared seven and ten days after inoculation respectively, on the wounded and nonwounded tissues, while the controls remained symptomless. Koch's postulates were accomplished after pathogen reisolation from inoculated plants. The fungus was also pathogenic to pea (Pisum sativum L.) cv. Maria, lentil (Lens esculenta Moench.) cv. Gesilba, and pigeon pea (Cicer arietinum L.) cv. Cícero, where it caused a typical crown and root rot. The fungus was identified at Universidade Federal de Viçosa, Forest Pathology, as Cylindrocladium spathiphylli Schoult, El-Gholl \& Alfieri (teleomorph - Calonectria spathiphylli El-Gholl, Uschida, Alfenas, Schub \& Alfieri). This species has rod shaped conidia $(54 \mu \mathrm{m} \times 5 \mu \mathrm{m})$ with one septum (Figure 1-D) and a globose vesicle measuring 12,3 $\mu \mathrm{m}$ diameter (Figure 1-E). The teleomorph was not observed either on paz (Spathiphyllum wllisii), causada por Cylindrocladium spathiphylli, no Distrito Federal. Plantas afetadas apresentam amarelecimento e murcha foliar, evoluindo para a morte, devido à podridão de colo e raiz.

infected plants or in pure culture. This disease was apparently first recorded in Florida (S.A. Alfieri Jr. et al. 1984, Index of plant diseases in Florida). The only report of this disease in Brazil was from the State of São Paulo (L.N. Coutinho $e$. al. 2001, Fitopatol. Bras. 26 (Suplem.):427), who described the pathogen as C. spathifilii. This is the first report of the disease in the Federal District, Brazil.

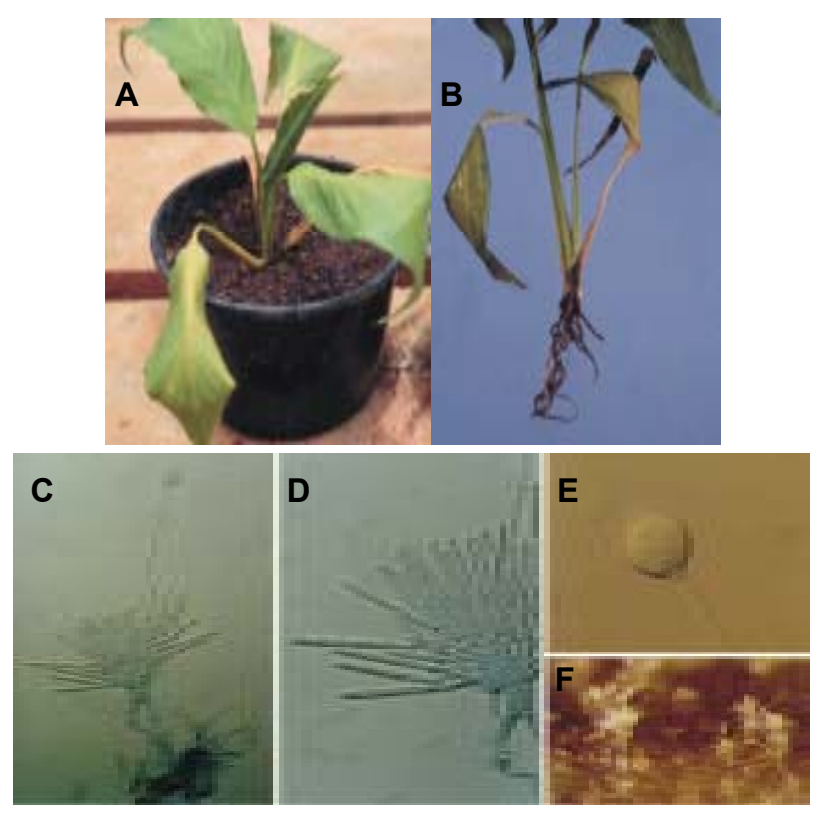

FIG. 1 - Yellowing and wilting of Spathiphyllum wallisii by Cylindrocladium spathiphylli: A- wilted plant, presenting yellow leaves and B- collar and root rot; C- Typical fungal structures of $C$. spathiphylli; D- details of conidia and conidiophore; E- vesicle; Fwhite sporulation of fungi on the substract. 